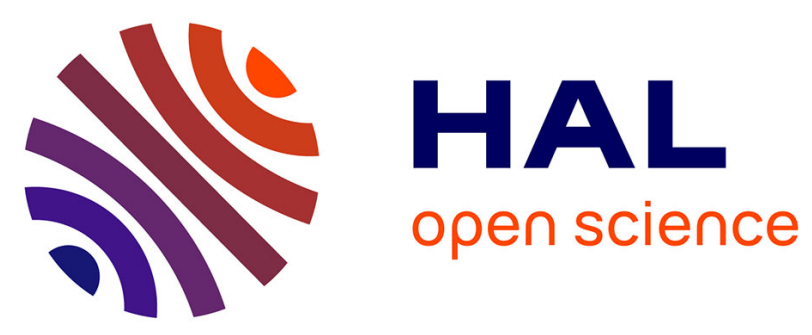

\title{
Artificial iron hydrogenase made by covalent grafting of Knölker's complex into xylanase: Application in asymmetric hydrogenation of an aryl ketone in water
}

Kalani Kariyawasam, Wadih Ghattas, Yossef López de Los Santos, Nicolas

Doucet, Sylvain Gaillard, Jean-Luc Renaud, Frédéric Avenier, Jean-pierre

Mahy, Rémy Ricoux

\section{To cite this version:}

Kalani Kariyawasam, Wadih Ghattas, Yossef López de Los Santos, Nicolas Doucet, Sylvain Gaillard, et al.. Artificial iron hydrogenase made by covalent grafting of Knölker's complex into xylanase: Application in asymmetric hydrogenation of an aryl ketone in water. Biotechnology and Applied Biochemistry, 2020, Synthetic and Engineered Enzymes for Biocatalysis and Biotransformation, 67, pp.563-573. 10.1002/bab.1906 . hal-03098292

\section{HAL Id: hal-03098292}

https://hal-normandie-univ.archives-ouvertes.fr/hal-03098292

Submitted on 5 Jan 2021

HAL is a multi-disciplinary open access archive for the deposit and dissemination of scientific research documents, whether they are published or not. The documents may come from teaching and research institutions in France or abroad, or from public or private research centers.
L'archive ouverte pluridisciplinaire $\mathbf{H A L}$, est destinée au dépôt et à la diffusion de documents scientifiques de niveau recherche, publiés ou non, émanant des établissements d'enseignement et de recherche français ou étrangers, des laboratoires publics ou privés. 


\title{
Artificial iron hydrogenase made by covalent grafting of Knölker's complex into xylanase: Application in asymmetric hydrogenation of an aryl ketone in water
}

\author{
${ }^{1}$ Institut de Chimie Moléculaire et des Matériaux d'Orsay (ICMMO), UMR \\ 8182 CNRS, Laboratoire de Chimie Bioorganique et Bioinorganique, \\ Université Paris-sud, Université Paris-Saclay, Orsay cedex, France \\ ${ }^{2}$ Centre Armand-Frappier Santé Biotechnologie, Institut National de la \\ Recherche Scientifique (INRS), Université du Québec, Réseau International \\ des Instituts Pasteur, Laval (Québec), Canada \\ ${ }^{3}$ Université de Caen-Ecole Nationale Supérieure d'Ingénieurs de Caen \\ Laboratoire de Chimie Moléculaire et Thioorganique - UMR CNRS 6507, \\ Caen, France
}

\section{Abstract}

We report a new artificial hydrogenase made by covalent anchoring of the iron Knölker's complex to a xylanase S212C variant. This artificial metalloenzyme was found to be able to catalyze efficiently the transfer hydrogenation of the benchmark substrate trifluoroacetophenone by sodium formate in water, yielding the corresponding secondary alcohol as a racemic. The reaction proceeded more than threefold faster with the XInS212CK biohybrid than with the Knölker's complex alone. In addition, efficient conversion of trifluoroacetophenone to its corresponding alcohol was

Keywords: artificial metalloenzymes, catalysis, hydrogenation, Knölker's complex

Abbreviations: $C I D$, card identification number; DIBALH,

diisobutylaluminium hydride; DTNB, 5,5-dithio-bis-(2-nitrobenzoic acid); HEPES, 4-(2-hydroxyethyl)-1-piperazineethanesulfonic acid; MALDI Tof MS, matrix-assisted laser desorption/ionizationtime-of-flight mass spectrometry; MVD, molegro virtual docker; NMA, normal mode analysis; NMR, nuclear magnetic Resonance; PDB, protein data bank; SDS PAGE, sodium dodecylsulfate polyacrylamide gel electrophoresis; TFAC, trifluoroacetophenone; TMS, tetramethylsilane; TpCPP, tetra-4-carboxyphenyporphyrin; TpSPP, tetra-4-sulfonatophenlyporphyrin; TSB, Tryptic soy broth; TNB, 2-nitro-5-thiobenzoate; XIn A, xylanase A. *Address for correspondence: Prof. Jean-Pierre Mahy, PhD, Institut de Chimie Moléculaire et des Matériaux d'Orsay (ICMMO), UMR 8182 CNRS, Laboratoire de Chimie Bioorganique et Bioinorganique, Bât. 420, Université Paris-sud, Université Paris-Saclay, 91405 Orsay cedex, France. Ph. + 331 691574 21; Fax. + 331691572 81; e-mail: Jean-pierre.mahy@u-psud.fr Received 19 November 2019; accepted 2 March 2020

\author{
Kalani Kariyawasam ${ }^{1}$ \\ Wadih Ghattas (D) 1 \\ Yossef López De Los Santos (iD2 \\ Nicolas Doucet iD 2 \\ Sylvain Gaillard (iD 3 \\ Jean-Luc Renaud (D) 3 \\ Frédéric Avenier (iD) 1 \\ Jean-Pierre Mahy (D) 1* \\ Rémy Ricoux 1
}

reached within $60 \mathrm{H}$ with $\mathrm{XInS} 212 \mathrm{CK}$, whereas a $\approx 2.5$-fold lower conversion was observed with Knölker's complex alone as catalyst. Moreover, the data were rationalized with a computational strategy suggesting the key factors of the selectivity. These results suggested that the Knölker's complex was most likely flexible and could experience free rotational reorientation within the active-site pocket of XIn A, allowing it to access the subsite pocket populated by trifluoroacetophenone. (c) 2020 International Union of Biochemistry and Molecular Biology, Inc. Volume 00, Number 0, Pages 1-11, 2020

\section{Introduction}

The reduction of polarized multiple bonds (ketones, imines, etc.) plays a major role in modern organic synthesis. This reaction can be carried out using metal hydrides such as $\mathrm{LiAlH}_{4}$ [1], 
or agrochemical products. To this end, alternative synthesis routes are now commonly used, involving the metallo-catalyzed version of reduction reactions such as hydrogenation under high pressure of molecular hydrogen and hydrogen transfer reactions in the presence of a hydrogen atom donor [5]. Depending on the nature of the metal and its ligands, the main advantage of this approach is the possibility to control regio-, chemo-, and/or stereoselectivity of the reaction. Unfortunately, the most commonly used catalysts for this type of reaction are based on weakly available, expensive, and toxic noble metals such as ruthenium [5], iridium [6], or rhodium [7]. The development of cheaper, more efficient, and eco-compatible catalysts has become a challenge of modern chemistry. In this context, iron-catalyzed hydrogenation has recently emerged as the most economical and environmentally preferred route of synthesis. It was recently demonstrated that Knölker-type iron complexes could be efficient catalysts for the hydrogenation of aromatic ketones in water [8]. However, this prior report has revealed that the reaction temperature was also decisive since no conversion was observed at $40{ }^{\circ} \mathrm{C}$, and only $13 \%$ conversion was observed at $60{ }^{\circ} \mathrm{C}$.

In addition to the enantioselective transformations catalyzed by metal complexes, catalysis by artificial metalloenzymes has become an interesting tool for the synthesis of enantiopure compounds in water [9]. This technology combines the attractive features of enzymatic catalysis with those of chemical catalysis [10]. Given the great potential of these biohybrid catalysts in asymmetric synthesis and, knowing that Knölker's iron complexes are efficient catalysts in water, a recent report illustrated the synthesis of biotinylated Knölker's complexes incorporated into streptavidin using the so-called "Trojan horse" strategy [11]. The artificial iron hydrogenases thus prepared catalyzed the reduction of ketones in aqueous medium, with the best conversion rates (26\%) and enantiomeric excess (34\%) obtained with para-methoxy-acetophenone as substrate [11].

Xylanases hydrolyze $\beta-1,4$ glycosidic bonds in the main chain of xylan, the major component of plant cell wall hemicellulose. In the pulp-bleaching process, the enzymatic hydrolysis of xylan at high temperature has gained importance from an environmental standpoint. Consequently, growing interest in temperature-tolerant xylanases working under extreme $\mathrm{pH}$ and ionic strength conditions has led to the discovery, cloning, and characterization of numerous enzymes. This includes xylanase A (Xln A) from Streptomyces lividans, an enzyme exhibiting optimal activity at $60{ }^{\circ} \mathrm{C}$ and $\mathrm{pH} 6$ [12]. This robust biocatalyst can also be easily purified, and its sequence and three-dimensional structure are known [13], making it a good scaffold for the production of artificial metalloenzymes. It has been shown that noncovalently inserted Fe(III) and Mn(III) complexes of anionic porphyrins into Xln A leads to artificial metalloenzymes, exhibiting good peroxidase activity [12]. In addition, the Fe(III)-porphyrin-based hybrid biocatalysts $\mathrm{Fe}(\mathrm{III})(\mathrm{TpCPP})$ - and $\mathrm{Fe}(\mathrm{III})(\mathrm{TpSPP})$-Xln A were found to catalyze the stereoselective oxidation of thioanisole in the presence of imidazole with roughly $40 \%$ enantiomeric excess

\section{Highlights}

- We report a new artificial hydrogenase made by covalent anchoring of the iron Knölker's complex to a xylanase variant.

- This artificial metalloenzyme was found to be able to catalyze efficiently the transfer hydrogenation of aromatic ketones by sodium formate in water, yielding the corresponding secondary alcohol as a racemic.

- The data were rationalized with a computational strategy and suggested that the Knölker's complex was most likely flexible and could experience free rotational reorientation within the active-site pocket of xylanase, allowing it to access the subsite pocket populated by substrata.

$[14,15]$. The most efficient biohybrid was undoubtedly observed for the stereoselective oxidation of styrene derivatives by oxone, catalyzed by the Mn(III)(TpCPP)-Xln A hemozyme, which led to an $80 \%$ ee in favor of the R isomer in the particular case of $p$-methoxystyrene [16].

In this paper, we report the preparation and characterization of a new artificial metalloenzyme that was obtained by the covalent attachment of a Knölker-type iron complex into xylanase A. This artificial metalloenzyme can efficiently catalyze the transfer hydrogenation of the benchmark substrate trifluoroacetophenone (TFAC) by sodium formate in water, yielding the corresponding secondary alcohol as a racemic. The reaction proceeded more than threefold faster with the XInS212CK biohybrid than with the Knölker's complex alone. In addition, efficient conversion of TFAC to its corresponding alcohol was reached within $60 \mathrm{H}$ with $\mathrm{XInS} 212 \mathrm{CK}$, whereas $\mathrm{a} \approx 2.5$-fold lower conversion was observed with Knölker's complex alone as catalyst.

\section{Experimental}

\subsection{Physical measurements}

UV-visible spectroscopy studies were performed on double beam UVIKON 860XL and Cary 300BIO Varian spectrophotometers.

${ }^{1} \mathrm{H}$ NMR and ${ }^{13} \mathrm{C}$ NMR spectra were recorded on Bruker AM 250, 300, and 360 spectrometers. Chemical shifts $\delta$ are given in ppm using the solvent as internal reference with respect to tetramethylsilane (TMS). Electrospray ionization mass spectrometry experiments were carried on a MicrOTOFQ Bruker spectrometer.

\subsection{Preparation of the Knölker's complex}

\subsubsection{3-(Trimethylsilyl)prop-2-yn-1-ol (S1) [11]}

In a two-necked round bottom flask under argon atmosphere, a $2.5 \mathrm{M}$ solution of $n \mathrm{BuLi}$ in hexane $(34.5 \mathrm{~mL}, 86.3 \mathrm{mmol})$ was added dropwise to a solution of propargylic alcohol (2.1 $\mathrm{g}, 37.5 \mathrm{mmol}$ ) in $100 \mathrm{~mL}$ dry $\mathrm{THF}$ at $-78{ }^{\circ} \mathrm{C}$. The solution 
was slowly warmed up to room temperature and stirred for an additional $1 \mathrm{H}$. The reaction mixture was cooled down to $-78{ }^{\circ} \mathrm{C}$, and trimethylsilyl chloride $(11 \mathrm{~mL}, 86.3 \mathrm{mmol})$ was slowly added. The resulting mixture was stirred at room temperature overnight. The reaction was then cooled down to $0{ }^{\circ} \mathrm{C}$, and an aqueous solution of $2.6 \mathrm{~mL}$ of $95 \%$ sulfuric acid in $15 \mathrm{~mL}$ of water was added slowly. The resulting solution was stirred for an additional $3 \mathrm{H}$ at room temperature. Water (20 $\mathrm{mL}$ ) was added until dissolution of the inorganic salts. The aqueous layer was extracted with diethyl ether $(3 \times 50$ mL). Organic layers were dried over $\mathrm{Na}_{2} \mathrm{SO}_{4}$ and filtered, and the solvent was removed under reduced pressure. The crude product was purified by distillation (3.5 g, $73 \%$ ).

${ }^{1} \mathrm{H}$ NMR $\left(\mathrm{CDCl}_{3}, 300 \mathrm{MHz}\right), \delta(\mathrm{ppm} / \mathrm{TMS}): 4.27(\mathrm{~d}, J=4.9$ $\mathrm{Hz}, 2 \mathrm{H}), 0.18$ (s, 9H).

\subsubsection{3-(Trimethylsilyl)prop-2-ynyl bromide (S2) [11, $17]$}

In a three-necked round bottom flask under argon atmosphere, a 1 M solution of bromine in dry dichloromethane $(38.4 \mathrm{~mL}, 38.4$ mmol) was added dropwise to a solution of triphenylphosphine (10 g, $38.4 \mathrm{mmol})$ in $200 \mathrm{~mL}$ dry dichloromethane at $0{ }^{\circ} \mathrm{C}$. Pyridine (2.55 mL, $32 \mathrm{mmol}$ ) was then added, followed by the addition of a solution of S1 (4.1 g. $32 \mathrm{mmol}$ ) in $50 \mathrm{~mL}$ dry dichloromethane at $0{ }^{\circ} \mathrm{C}$. The resulting mixture was stirred at $0{ }^{\circ} \mathrm{C}$ for $2 \mathrm{H}$ and then at room temperature for $4 \mathrm{H}$. Pentane $(500 \mathrm{~mL})$ was then added, which resulted in the formation of a precipitate of triphenylphosphine oxide. The solution was then filtered through a pad of Celite ${ }^{\circledR}$, and silica and the solvents were removed under reduced pressure to afford compound S2 as a colorless oil (4.16 g, 68\%).

${ }^{1} \mathrm{H}$ NMR $\left(\mathrm{CDCl}_{3}, 300 \mathrm{MHz}\right) \delta(\mathrm{ppm} / \mathrm{TMS}): 3.91(\mathrm{~s}, 2 \mathrm{H}), 0.18$ (s, 9H).

\subsection{3. tert-Butyl(2-aminoethyl)carbamate (S3) [11, 17]}

In a two-necked round bottom flask under argon atmosphere, a solution of $\mathrm{Boc}_{2} \mathrm{O}(1 \mathrm{~g}, 4.6 \mathrm{mmol})$ in $25 \mathrm{~mL}$ dry dichloromethane was added dropwise to a solution of ethylenediamine $(10 \mathrm{~mL}$, $150 \mathrm{mmol}$ ) in $40 \mathrm{~mL}$ dry dichloromethane at $0{ }^{\circ} \mathrm{C}$. The reaction mixture was stirred $1 \mathrm{H}$ at $0{ }^{\circ} \mathrm{C}$ and then overnight at room temperature. Water $(40 \mathrm{~mL})$ was added, and the organic layer was recovered, washed twice with $40 \mathrm{~mL}$ water, and dried over $\mathrm{Na}_{2} \mathrm{SO}_{4}$. After filtration, the solvent was removed under reduced pressure and the residue was purified by chromatography on a neutral alumina column eluted with ethyl acetate/methanol (95/5) to afford S3 as a colorless oil (0.42 g, 57\%).

${ }^{1} \mathrm{H}$ NMR $\left(\mathrm{CDCl}_{3}, 300 \mathrm{MHz}\right), \delta$ (ppm/TMS): 4.86 (br s, 1H), 3.17 (q, $J=5.9 \mathrm{~Hz}, 2 \mathrm{H}), 2.80$ (t, $J=5.9 \mathrm{~Hz}, 2 \mathrm{H}), 1.44$ (s, 9H), 1.42 (br s, 2H).

ESI-MS $m / z[\mathrm{M}+\mathrm{H}]^{+}$: Calc. 161.1285, Found 161.1284.

\subsubsection{N-tert-Butoxycarbonyl, $\mathrm{N}^{\prime}$-maleimido- ethylenediamine (S4) [17]}

In a round bottom flask, $N$-methoxy-carbonyl maleimide (119 $\mathrm{mg}, 0.77 \mathrm{mmol}$ ) was dissolved in $10 \mathrm{~mL}$ of a saturated aqueous $\mathrm{NaHCO}_{3}$ solution on ice. The reaction mixture was stirred 40
Min on ice and then $1 \mathrm{H} 30 \mathrm{Min}$ at room temperature. The $\mathrm{pH}$ of the solution was adjusted to 3 with concentrated $\mathrm{H}_{2} \mathrm{SO}_{4}$ on ice. The aqueous layer was then extracted with ethyl acetate $(3 \times 150 \mathrm{~mL})$. Organic layers were dried over $\mathrm{Na}_{2} \mathrm{SO}_{4}$, filtered and the solvent was removed under reduced pressure. The crude product was then purified by chromatography on a silica gel column eluted with heptane/ethyl acetate (1/1) to afford S4 as a white solid (131 mg, 71\%).

${ }^{1} \mathrm{H}$ NMR $\left(\mathrm{CDCl}_{3}, 300 \mathrm{MHz}\right), \delta(\mathrm{ppm} / \mathrm{TMS}): 4.86(b r \mathrm{~s}, 1 \mathrm{H})$, $3.17(\mathrm{q}, J=5.9 \mathrm{~Hz}, 2 \mathrm{H}), 2.80(\mathrm{t}, J=5.9 \mathrm{~Hz}, 2 \mathrm{H}), 1.44(\mathrm{~s}, 9 \mathrm{H})$, 1.42 (br s, 2H).

\subsubsection{N-(2-Aminoethyl)maleimide (S5) [17, 18]}

In a round bottom flask, compound $\mathbf{S 4}(130 \mathrm{mg}, 0.54 \mathrm{mmol})$ was dissolved in $2 \mathrm{~mL}$ dichloromethane at $0^{\circ} \mathrm{C}$. TFA $(760 \mu \mathrm{L}$, $9.9 \mathrm{mmol}$ ) was added and the resulting solution was stirred for $2 \mathrm{H}$ at room temperature. The mixture was concentrated to 1 $\mathrm{mL}$, and ice-cold diethyl ether $(2 \mathrm{~mL})$ was added. The obtained precipitate was filtered off and washed with ice-cold diethyl ether $(3 \times 10 \mathrm{~mL})$.

${ }^{1} \mathrm{H}$ NMR $\left(\mathrm{D}_{2} \mathrm{O}, 300 \mathrm{MHz}\right), \delta(\mathrm{ppm} / \mathrm{TMS}): 6.88(\mathrm{~s}, 2 \mathrm{H}), 3.81(\mathrm{t}$, $2 \mathrm{H}), 3.20(\mathrm{t}, 2 \mathrm{H})$.

ESI-MS $m / z[\mathrm{M}+\mathrm{H}]^{+}$: Calc. 141.0659, Found 141.0664

\subsubsection{1-(2-(Bis(3-(trimethylsilyl)prop-2-yn-1- yl)amino)ethyl)-1H-pyrrole-2,5-dione (S6) [11]}

In a round bottom flask under argon atmosphere, S5 (90.5 $\mathrm{mg}, 0.36 \mathrm{mmol}$ ) and $\mathbf{S 3}$ (136 $\mathrm{mg}, 0.71 \mathrm{mmol}$ ) were added in $20 \mathrm{~mL}$ of dry acetonitrile. $N, N$-Diisopropylethylamine $(63 \mu \mathrm{L}$, $0.36 \mathrm{mmol}$ ) was added, and the resulting mixture was stirred for $2 \mathrm{H}$ at room temperature, and then for an additional $16 \mathrm{H}$ at $70{ }^{\circ} \mathrm{C}$. After cooling down, the solvent was removed under reduced pressure and $50 \mathrm{~mL}$ of water was added. The aqueous layer was then extracted with ethyl acetate $(3 \times 30 \mathrm{~mL})$. Organic layers were dried over $\mathrm{Na}_{2} \mathrm{SO}_{4}$ and filtered, and the solvent was removed under reduced pressure. The crude product was then purified with by chromatography on a silica gel column using a pentane/ ethyl acetate (95/5 to $90 / 10)$ gradient to obtain a white solid (70 mg, 54\%)

${ }^{1} \mathrm{H} \mathrm{NMR}\left(\mathrm{CDCl}_{3}, 300 \mathrm{MHz}\right), \delta(\mathrm{ppm} / \mathrm{TMS}): 7$ (s, 2H), $3.4(\mathrm{~s}$, $4 \mathrm{H}), 2.8(\mathrm{t}, 2 \mathrm{H}), 2.6(\mathrm{t}, 2 \mathrm{H}), 0.16(\mathrm{~s}, 18 \mathrm{H}) \mathrm{ppm}$.

${ }^{13} \mathrm{C}$ NMR $\left(\mathrm{CDCl}_{3}, 300 \mathrm{MHz}\right), \delta(\mathrm{ppm} / \mathrm{TMS}): 170.6\left(\mathrm{C}_{\mathrm{q}}\right), 134$ $(\mathrm{CH}), 100.8\left(\mathrm{C}_{\mathrm{q}}\right), 89.8(\mathrm{C} \mathrm{q}), 49.4\left(\mathrm{CH}_{2}\right), 43.4\left(\mathrm{CH}_{2}\right), 35.36\left(\mathrm{CH}_{2}\right)$, $-0.07\left(\mathrm{CH}_{3}\right)$.

ESI-MS $m / z[\mathrm{M}+\mathrm{H}]^{+}$: calcd. 361.1762, Found 361.1763.

\subsubsection{Knölker's complex (S7) [11]}

In a round bottom flask under argon atmosphere, S6 (122 mg, $0.34 \mathrm{mmol})$ and $\mathrm{Fe}_{2}(\mathrm{CO})_{9}(123 \mathrm{mg}, 0.34 \mathrm{mmol})$ were introduced in $5 \mathrm{~mL}$ degassed and dry toluene. The reaction mixture was heated at $110{ }^{\circ} \mathrm{C}$ for $14 \mathrm{H}$. The resulting brownish solution was cooled down to room temperature and purified by column chromatography on neutral alumina topped with a pad of Celite (eluent: dichloromethane/cyclohexane, 6/4) to afford the desired product $\mathbf{S 7}$ as a yellow-brown solid (95 mg, 53\%). 

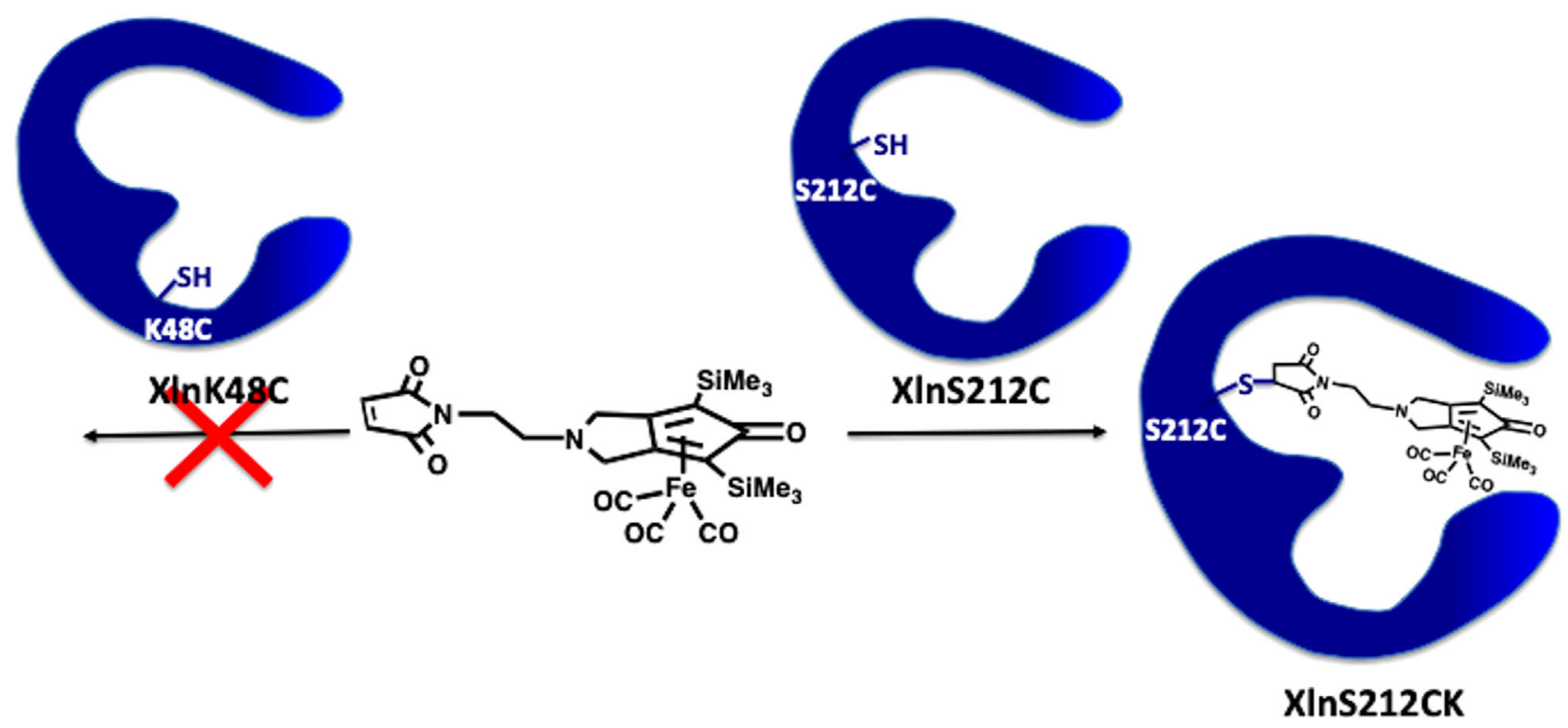

FIG. 1

Coupling of the S7 Knölker's complex to XInS212C and XInK48C enzyme variants : synthesis of the xylanase A-derived biohybrid XInS212CK.

${ }^{1} \mathrm{H}$ NMR $\left(\mathrm{CHCl}_{3}, 300 \mathrm{MHz}\right), \delta(\mathrm{ppm} / \mathrm{TMS}): 6.68(\mathrm{~s}, 2 \mathrm{H}), 3.88$ $(\mathrm{d}, 2 \mathrm{H}), 3.72(\mathrm{t}, 2 \mathrm{H}), 3.35(\mathrm{~d}, 2 \mathrm{H}), 3.04(\mathrm{t}, 2 \mathrm{H}), 0.24(\mathrm{~s}, 18 \mathrm{H})$.

${ }^{13} \mathrm{C}$ NMR $\left(\mathrm{CHCl}_{3}, 300 \mathrm{MHz}\right), \delta(\mathrm{ppm} / \mathrm{TMS}): 170.7\left(\mathrm{C}_{\mathrm{q}}\right), 134.1$ $(\mathrm{CH}), 112.9(\mathrm{C} q), 69.2\left(\mathrm{C}_{\mathrm{q}}\right), 53.3\left(\mathrm{CH}_{2}\right), 52.3\left(\mathrm{CH}_{2}\right), 36.5\left(\mathrm{CH}_{2}\right)$, $-0.8\left(\mathrm{CH}_{3}\right) \mathrm{ppm}$.

ESI-MS $m / z[\mathrm{M}+\mathrm{H}]^{+}$: Calcd. 529.0908, Found. 529.0908.

\subsection{Protein expression and purification}

Wild-type and mutant forms of Xln A were expressed and purified from the supernatant of $S$. lividans using a slightly modified version of a previously reported protocol [12]. Genetic constructs for cysteine mutants at positions K48 and S212 were a generous gift from Prof. Claude Dupont (INRS). Briefly, $S$. lividans was first precultured in $12 \mathrm{~mL}$ TSB medium for 2 days and further expressed for $72 \mathrm{H}$ at $34{ }^{\circ} \mathrm{C}$ by inoculation in M14 minimal medium using xylose as the sole carbon source. The culture supernatant was concentrated by ultrafiltration and dialyzed against $20 \mathrm{mM}$ citric buffer ( $\mathrm{pH}$ 4.5). The dialyzed enzyme solution was then loaded on a HiPrep CM FF 16/10 column (GE Healthcare) preequilibrated with $20 \mathrm{mM}$ citric buffer (pH 4.5). The enzyme was eluted with a linear gradient of the same buffer containing $1 \mathrm{M} \mathrm{NaCl}$. Fractions were collected, and protein elution was monitored at $280 \mathrm{~nm}$. Elution fractions were further analyzed by SDS-PAGE, and fractions containing XIn A were collected, pooled, dialyzed against water, and lyophilized.

\subsection{Monitoring of thiol accessibility}

The accessibility of the C212 thiol group was monitored using Ellman's test [19]. In a standard assay, $5 \mu \mathrm{L}$ of a $10 \mathrm{mM}$ solution 5,5'-dithio-bis-(2-nitrobenzoic acid) in water was added to $445 \mu \mathrm{L}$ of reaction buffer $(0.1 \mathrm{M}$ sodium phosphate $\mathrm{pH}$ 8.0, $1 \mathrm{mM}$ EDTA) in a 1-mL quartz cuvette. The absorbance at
$412 \mathrm{~nm}$ was then monitored as a function of time, using a Jasco spectrophotometer, after the addition of $50 \mu \mathrm{L}$ of a $100 \mu \mathrm{M}$ protein solution until complete reaction. The final absorbance obtained at the plateau was noted $A_{\text {eq }}$, and the initial absorbance measured before protein addition was noted $A_{0}$. The reduced cysteine content was then calculated from the difference in absorbance $A_{\text {eq }}-A_{0}$, corrected by the dilution factor, using an $\varepsilon_{\mathrm{M}}$ value of $14150 \mathrm{M}^{-1} \cdot \mathrm{cm}^{-1}$ at $412 \mathrm{~nm}$.

\subsection{Molecular modeling \\ 2.5.1. Construction of the Xln A-Knölker's biohybrid complex}

The crystal structure of XIn A from S. lividans (PDB entry 1E0W) was used as the starting template for construction of the Xln A-Knölker biohybrid complex [20]. To predict backbone perturbations caused by introduction of the S212C substitution, a standard RosettaBackub protocol was used [21]. The universal force field and steepest descent protocols available in the Avogadro 1.2.0 suite were applied to properly estimate conformation of the Knölker's molecule (including the Fe ion as transition metal). The XIn A-Knölker's complex was created using the Build-Structure tools available in UCSF Chimera 1.14. Amino acid residues in the vicinity of the Knölker's molecule were then energy minimized using the force field provided by the Molegro Virtual Docker suite 6.0 (MVD). Through this energy minimization step, the thermodynamic barriers between the Xln A receptor protein and Knölker's ligand were evaluated to extract the most realistic representations of this hybrid complex. During this particular analysis, both the Knölker's complex ligand and XIn A were first considered as separated entities.

\subsubsection{Conformational exchange experienced by $X \ln A$}

To simulate conformational exchange experienced by Xln A, we applied two coarse-grained methodologies that predict shortand long-range protein dynamics. To simulate local residue dynamics, the stochastic method based on a Monte Carlo 


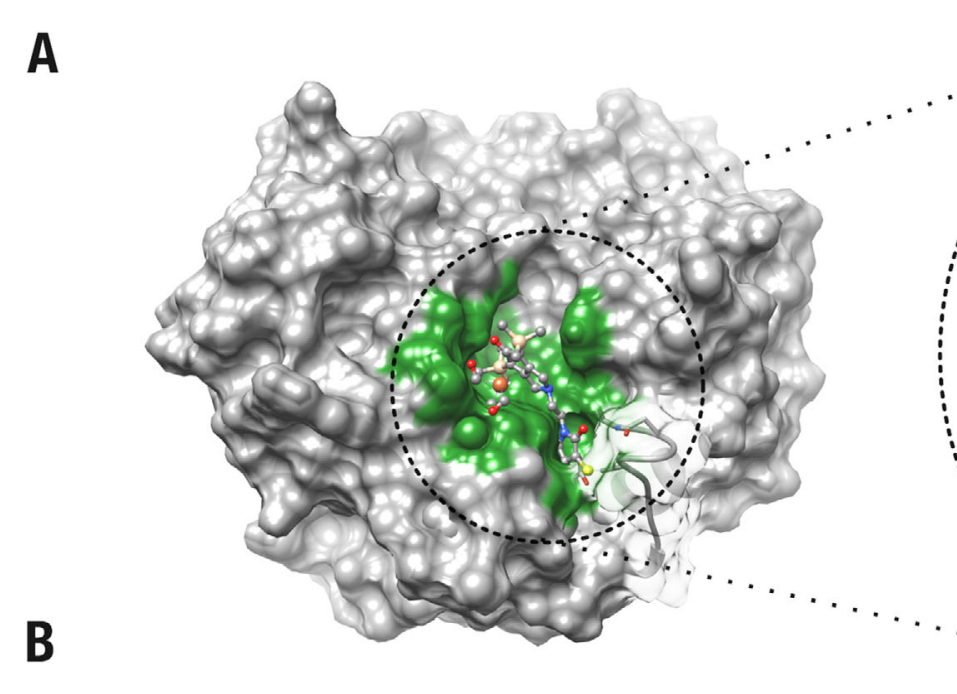

Local flexibility in XIn A (short-range Monte Carlo)

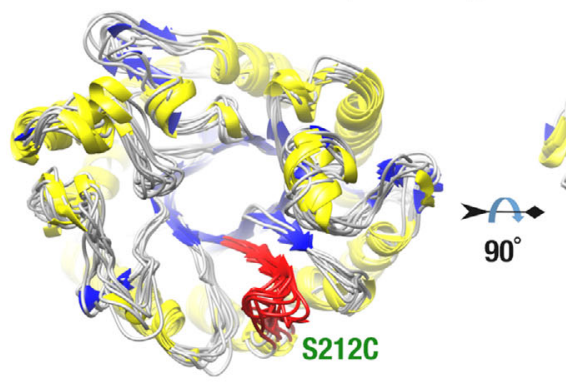

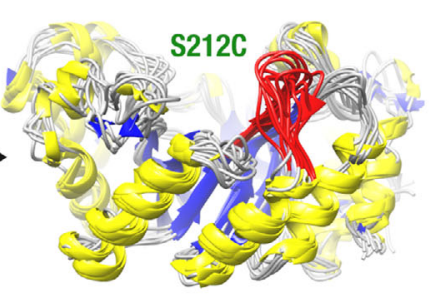

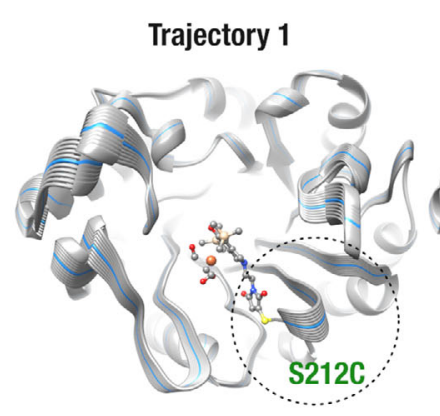

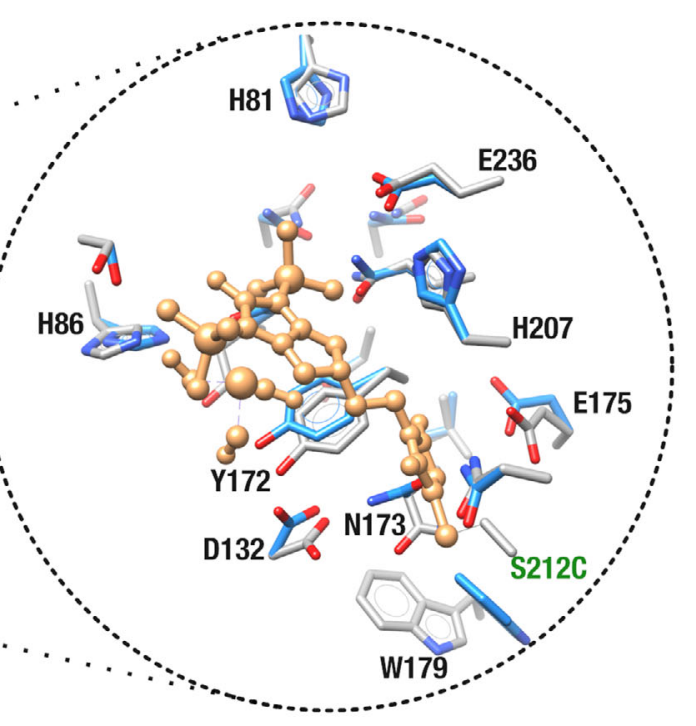

Long-range flexibility in XIn A (NMA)
FIG. 2 covalently anchored to XIn A. (A) Energy-minimized structure of XIn A covalently bound to the Knölker's complex at mutated position C212. The left panel shows the surface of the XIn A active-site cavity (green) bound to the Knölker's complex (ball-and-stick model). The right panel shows residue side chains that stabilize the Knölker's complex in the active-site cavity of XIn A. Surface transparency was applied to illustrate the active-site loop-harboring residue C212. Residue side chains are labeled and shown before (blue) and after (gray) energy minimization. The Knölker's complex is shown in sandy brown, and the $C 212$ substitution is labeled in green. (B) Molecular dynamics simulations illustrating short-range (left panel) and long-range (right panel) conformational exchange experienced by $X \ln A$. The C212 loop is colored red (left) and highlighted by a dashed circle (right). For long-range trajectory simulations, the starting XIn A conformer is shown as a blue ribbon.

analysis was applied using the CABSflex 2.0 server [22]. Default server parameters were used for this analysis, which recently demonstrated results comparable to other all-atoms MD simulations protocols (i.e., similar to 10-ns simulations in aqueous solvent) [23]. Long-range protein dynamics were predicted using a normal mode analysis (NMA) methodology through the ElNémo server [24]. NMA computed two trajectories with 10 models, corresponding to the lowest frequency normal modes. Parameters used a perturbation range of -100 and a cutoff of $8 \AA$ A. Collectivity scores were considered to manually select the best two elastic network models. All coarse-grained methodologies were performed using the S212C model obtained from the RosettaBackub server as starting PDB structure [21].

\subsubsection{Molecular docking simulations}

To simulate coordination of the Xln A-Knölker's biohybrid complex with the TFAC substrate molecule, we performed virtual docking simulations using the MolDock scoring function implemented in the MVD suite 6.0 [25]. The virtual docking procedure was performed in two sequential phases. We first performed blind (free) docking of the substrate on the whole biohybrid complex as receptor target, after which we used a reduced searching area acquired from the best docking conformers obtained from the first phase of the docking simulation. Simulations were performed without incorporation of water molecules, and the best conformers arose from a pool of 1,000,000 docking combinations. Results from both sequential phases were compiled from 500 iterations per run and 20 runs per process. The ligand molecule was obtained 

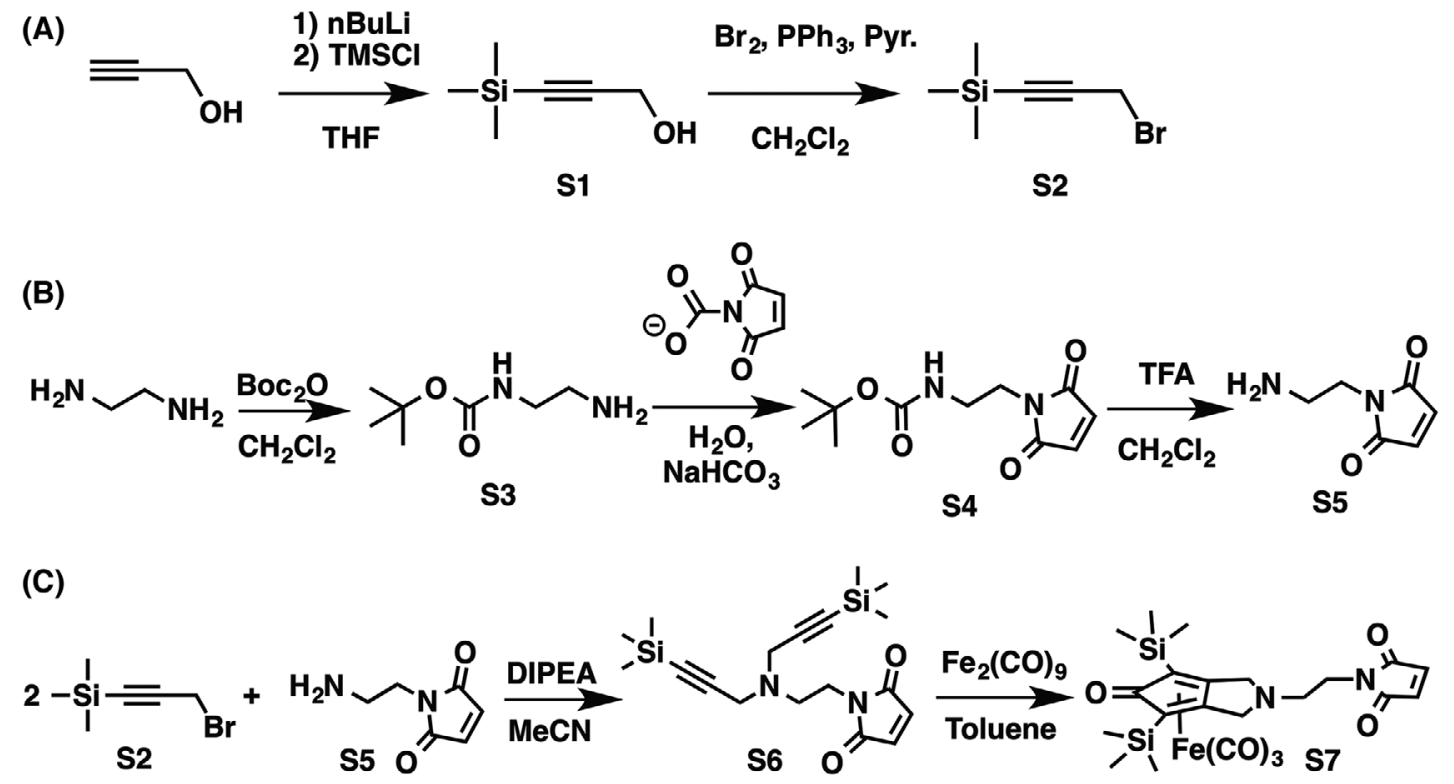

\section{SCHEME 1}

Synthesis of the Knölker's complex S7 [11, 17, 18].

from the PubChem database under accession CID number 9905.

\subsection{Coupling of the Knölker's complex to the S212C variant of $X \ln A$}

The concentration of accessible thiols calculated via Ellman's test was used as the free cysteine concentration available for the coupling of the Knölker's complex S7. Five equiv. of S7 diluted in DMSO was mixed with the Xylanase A S212C variant (XlnS212C) in the coupling buffer (HEPES $10 \mathrm{mM}, 150 \mathrm{mM} \mathrm{NaCl}$, $\mathrm{pH} 7.75$ ), for a final DMSO concentration of $2 \%$ in the desired volume. The mixture was incubated overnight at $4{ }^{\circ} \mathrm{C}$. The mixture was loaded on a gel filtration column (HiLoad 16/600 Superdex ${ }^{\mathrm{TM}} 75$, GE Healthcare) equilibrated in buffer A (HEPES $10 \mathrm{mM}, 150 \mathrm{mM} \mathrm{NaCl}, \mathrm{pH} 8$ ) that was previously incubated with Chelex $^{\circledR} 100$ resin and filtered. The coupling efficiency was measured by using Ellman's test and MALDI-TOF MS analysis. The molar extinction coefficient of the Knölker's complex was determined in HEPES $10 \mathrm{mM}$, NaCl $150 \mathrm{mM}$, pH 7 containing $5 \%$ ethanol and was found to be similar to that measured in ethanol, $\varepsilon_{\mathrm{M}}=3,100 \mathrm{M}^{-1} \cdot \mathrm{cm}^{-1}$ at $280 \mathrm{~nm}$. The molar extinction coefficient of the biohybrid at $280 \mathrm{~nm}$ was calculated by adding the computed molar extinction coefficient of the protein variant to that measured for the Knölker's complex moiety and was found to be $\varepsilon_{\mathrm{M}}=67,500 \mathrm{M}^{-1} \cdot \mathrm{cm}^{-1}$.

\subsection{Protein mass spectrometry analysis}

Protein solutions were desalted on a Zeba Spin column (Thermo) against $10 \mathrm{mM}$ HEPES buffer $\mathrm{pH} 8$ and then diluted in a sinapinic acid matrix for MALDI-ToF MS analysis in linear mode by using a MALDI-ToF/ToF UltrafleXtreme spectrometer (Bruker Daltonics).

\subsection{Catalysis of the hydrogen transfer reaction}

Reactions were carried out in $1 \mathrm{~mL}$ sealed vials for a $200-\mu \mathrm{L}$ reaction volume. In each vial, $86.2 \mu \mathrm{L}$ of a $69.6 \mu \mathrm{M}$ XInS212CK solution in $10 \mathrm{mM}$ HEPES $150 \mathrm{mM} \mathrm{NaCl} \mathrm{pH} 8$ (final concentration: $30 \mu \mathrm{M}), 5 \mu \mathrm{L}$ of a $3.6 \mathrm{mM} \mathrm{Me}{ }_{3} \mathrm{NO}$ solution in water (final concentration: $90 \mu \mathrm{M}$ ), $40.8 \mathrm{mg}$ of sodium formate (final concentration: $3 \mathrm{M}$ ), and $10 \mu \mathrm{L}$ of a $500 \mathrm{mM}$ TFAC solution in ethanol (final concentration: $25 \mathrm{mM}$ ) and $10 \mathrm{mM}$ HEPES $150 \mathrm{mM} \mathrm{NaCl}$ pH 8 were added for a final volume of $200 \mu \mathrm{L}$ with $7.5 \%$ of EtOH. The vials were tightly closed and set in a dry block (Reacti-therm heating and stirring module) heated at $65^{\circ} \mathrm{C}$ with a vigorous stirring. The reaction was stopped after various times, and $20 \mu \mathrm{L}$ of a $31 \mathrm{mM}$ acetophenone solution in acetonitrile was then added. The organic products were then extracted twice with $500 \mu \mathrm{L}$ of ethyl acetate, dried with $\mathrm{Na}_{2} \mathrm{SO}_{4}$ and filtered. The samples were then analyzed by GC.

GC conditions used to determine the conversion: Zebron ZB semivolatiles column ( $25 \mathrm{~m}, 0.25 \mathrm{~mm}, 0.25 \mu \mathrm{m})$ and helium vector gaz. Injector temperature: $300{ }^{\circ} \mathrm{C}$, oven temperature : $50-54{ }^{\circ} \mathrm{C}, 1{ }^{\circ} \mathrm{C} \cdot \mathrm{Min}^{-1}$, then $54-150{ }^{\circ} \mathrm{C}, 15^{\circ} \mathrm{C} \cdot \mathrm{Min}^{-1}$, and $150-$ $220{ }^{\circ} \mathrm{C}, 50{ }^{\circ} \mathrm{C} \cdot \mathrm{Min}^{-1}$, then hold at $220{ }^{\circ} \mathrm{C}$ for $1 \mathrm{Min}$. Detection by FID at $300{ }^{\circ} \mathrm{C}$

GC conditions used to determine the $e e$ of the product: hydrodex y-DiMOM column $(25 \mathrm{~m}, 0.25 \mathrm{~mm}, 0.25 \mu \mathrm{m})$ and helium vector gaz. Injector temperature: $240{ }^{\circ} \mathrm{C}$, oven temperature: $100-118^{\circ} \mathrm{C}, 5^{\circ} \mathrm{C} \cdot \mathrm{Min}^{-1}$ hold $15 \mathrm{Min}$, then $118-150{ }^{\circ} \mathrm{C}$, $10{ }^{\circ} \mathrm{C} \cdot \mathrm{Min}^{-1}$ and hold for 1 Min Detection by FID at $300{ }^{\circ} \mathrm{C}$.

\section{Results and Discussion}

\subsection{XIn A mutant selection and modeled biohybrid formation}

Covalently attaching an artificial complex to the active-site cavity of an enzyme to yield a newly designed, stable, and active biocatalyst remains a challenging task to this day, 


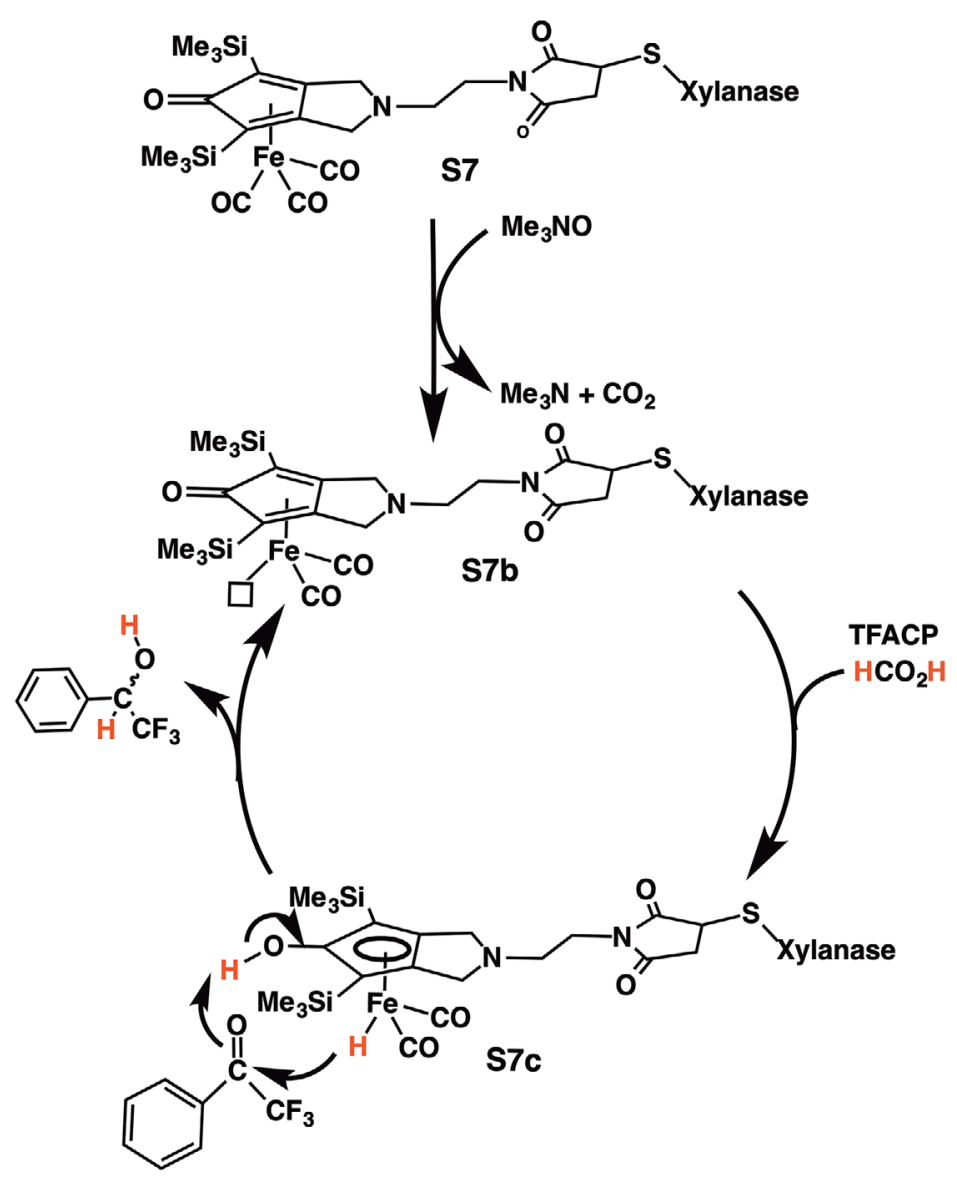

Postulated mechanism of the catalytic

SCHEME 2 hydrogenation by iron artificial metalloenzyme in water.

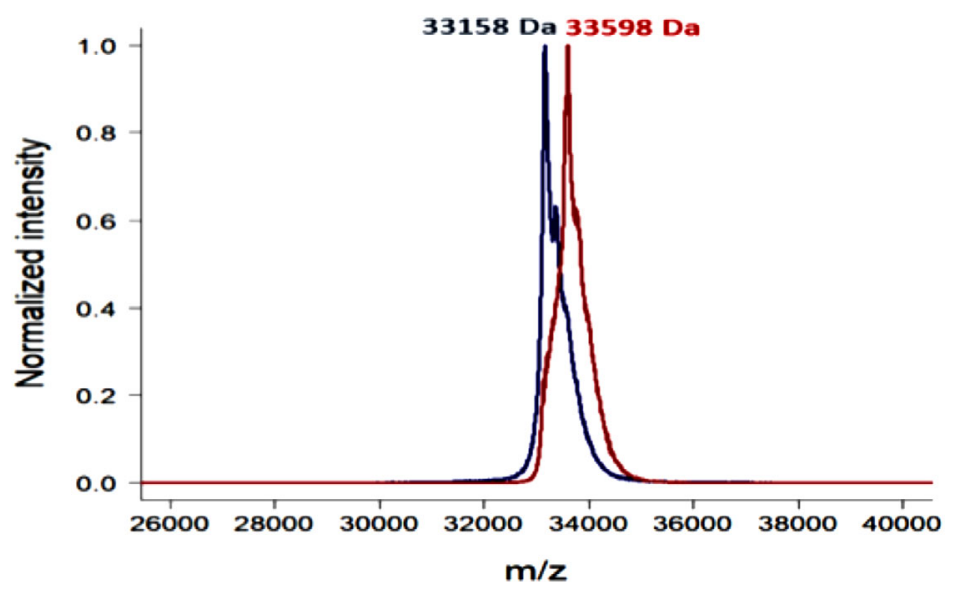

FIG. 3

Maldi-ToF spectra of the XInS212C variant measured before (blue) and after (red) functionalization with the Knölker's complex compound.<smiles>O=C(c1ccccc1)C(F)(F)F</smiles>

S8

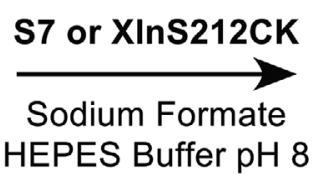<smiles>OC(c1ccccc1)C(F)(F)F</smiles>

S9 HEPES Buffer pH 8
FIG. 4

Hydrogenation of TFAC $\mathbf{S 8}$ by sodium formate XInS212CK biohybrid.

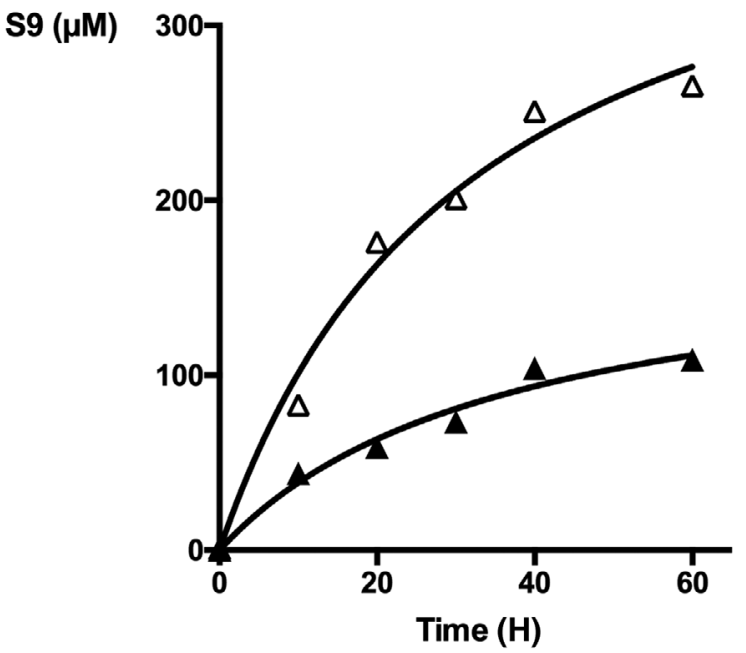

FIG. 5

Time course of hydrogenation of TFAC by $X \operatorname{InS} 212 C K(\triangle)$ in aqueous buffer in comparison with $\mathrm{CK}$ alone in $\mathrm{EtOH}(\mathbf{\Delta})$. catalyzed by Knölker's complex $\mathbf{S} 7$ or by the

especially in light of issues pertaining to protein and biohybrid stability. To help with proper positioning and orientation of the Knölker's complex in the solvent-exposed active site of $\mathrm{Xln}$ A, active-site residues $\mathrm{K} 48$ and S212 were selected as potential targets for cysteine mutagenesis, in addition to being subjected to molecular modeling investigation. Residues K48 and S212 are located on opposite sides of the active-site cavity, allowing subsequent formation of a covalent adduct between the enzyme and the Knölker's complex using the free thiol group of the cysteine side chain. Our experimental results showed that biohybrid formation was unsuccessful at residue 48 , most likely due to unfavorable steric clashes between the enzyme and the Knölker's complex upon covalent anchoring at this position (Fig. 1). However, coupling of the Knölker's complex to Xln A mutant S212C was successfully achieved, yielding the XlnS212CK enzyme variant (Fig. 1).

In accordance with experimental results, molecular modeling confirmed that the Knölker's complex can be accommodated in the active-site of XIn A upon covalent anchoring at this position (Fig. 2A).

However, the MolDock scoring function of the MVD force field revealed that this biohybrid remains energetically unfavorable when subjected to side-chain energy stabilization in the 


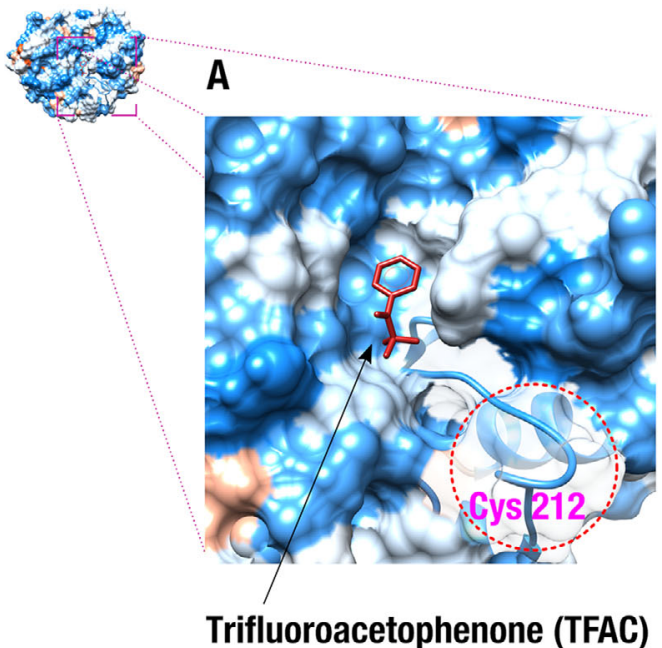

C

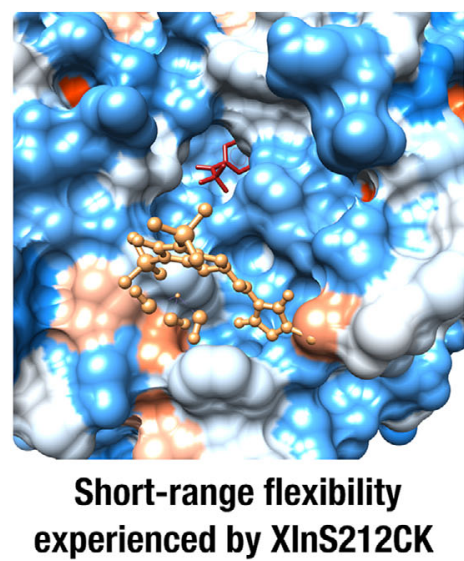

B

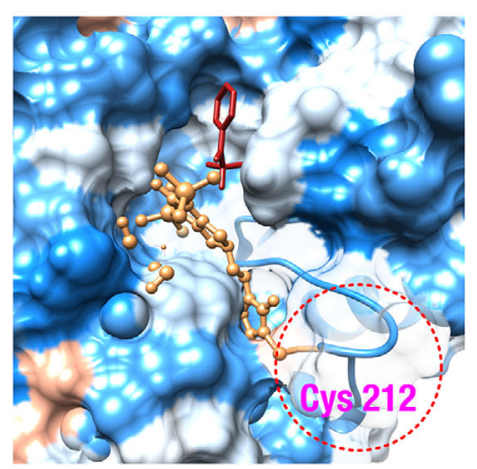
XInS212C cavity minimized with Knölker and TFAC

D

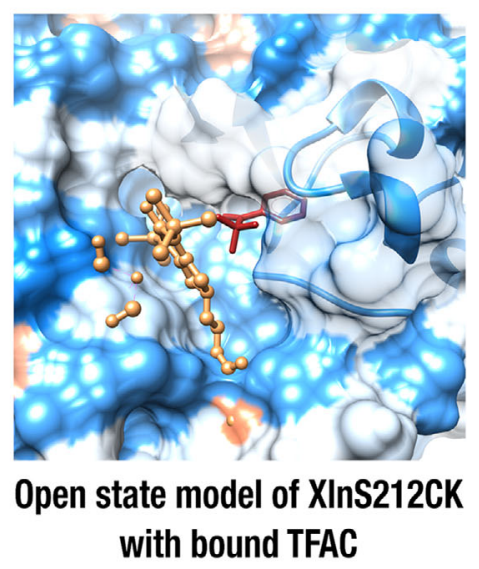

FIG. 6

\begin{abstract}
Virtual docking of the TFAC substrate to the XInS212C and XInS212CK biohybrid complexes used as receptor targets. (A) Blind virtual docking of TFAC to the XInS212C variant obtained from the RosettaBackrub server. (B) Docking of TFAC to the energetically minimized cavity of the XInS212CK biohybrid complex. (C) Docking of TFAC to an energetically favorable XInS212CK conformer extracted from Monte Carlo simulations. (D) Virtual docking of TFAC to the open state conformation of XInS212CK, obtained from NMA. In all structures, TFAC and the Knölker's complex are colored red and sandy brown, respectively. Red and blue protein surfaces highlight hydrophobic and hydrophilic surface areas, respectively.
\end{abstract}

vicinity of the active-site cavity. Even after energy minimization, residues delineating the catalytic pocket of Xln A remain highly unstable $(\approx 80 \mathrm{kcal} / \mathrm{mol}$ for the biohybrid complex) (Fig. $2 \mathrm{~A}$, right panel). These results illustrate that an energy contribution is required to stabilize the Knölker's complex and to establish proper thermodynamic conditions essential for enzyme-ligand stabilization. This also strongly suggests that formation of the
XIn A-Knölker's biohybrid requires conformational rearrangements within the protein scaffold.

To provide a more realistic model representation of the experimentally observed biohybrid complex, we performed Monte Carlo and NMA simulations to estimate short- and longrange conformational exchange experienced by the enzyme in solution. Coarse-grained simulations strongly suggest that the active-site cavity of Xln A experiences short- and longrange conformational rearrangements to allow Knölker's complex stabilization within the active-site cavity (Fig. 2B). Upon structural reorganization, energetically favorable protein conformers that stabilize biohybrid complex formation were readily observed, specifically for short-range flexibility models, which displayed favorable biohybrid complex energy values ( $\Delta G$ up to $-20 \mathrm{kcal} / \mathrm{mol}$ ).

\subsection{Synthesis of the Knölker's complex (S7)}

The Knölker's complex (S7) bearing a maleimido group that enables its covalent anchoring into the $\mathrm{XlnS212C}$ variant by reaction with the thiol function of C212 was prepared in seven steps, as described in Scheme 1. 
Tert-butyl(2-aminoethyl)carbamate S3 was first prepared in an overall $50 \%$ yield in two steps starting by the trimethyl silylation of propargylic alcohol by trimethylsilyl chloride, followed by a bromination by $\mathrm{Br}_{2}$ in the presence of triphenyl phosphine and pyridine in dichloromethane, as described in the literature (Scheme 1) [11, 17]. $N$-(2-Aminoethyl)maleimide S5 was then prepared in an overall $40 \%$ yield in three steps involving the monoprotection of one amino group of ethylenediamine by $\mathrm{Boc}_{2} \mathrm{O}$, followed by the introduction of the maleimido group by peptide coupling with $N$-methoxy-carbonyl maleimide in the presence of sodium hydrogenocarbonate and, finally, deprotection of the amino group by trifluoroacetic acid (Scheme 1) [17, 18]. The 1-(2-(bis(3-(trimethylsilyl)prop2-yn-1-yl)amino)ethyl)-1H-pyrrole-2,5-dione ligand (S6) was then obtained in a $54 \%$ yield by reaction of S3 with S5 in dry acetonitrile in the presence of $N, N$-diisopropylethylamine, as described in the Experimental section [11]. Final introduction of the iron(III) ion was performed by reaction of S7 with $\mathrm{Fe}_{2}(\mathrm{CO})_{9}$ in dry toluene under inert atmosphere, producing the S7 Knölker's complex at 53\% yield, which was then fully characterized by ${ }^{1} \mathrm{H}$ and ${ }^{13} \mathrm{C}$ NMR and ESI MS.

\subsection{Synthesis and characterization of the XInS212CK biohybrid}

The reactivity and accessibility of the thiol function of cysteine 212 in the XInS212C enzyme variant was first assessed by the time-resolved Ellman's assay using sulfhydryl reagent 5,5-dithio-bis-(2-nitrobenzoic acid) (DTNB) that reacts with sulfhydryl groups and releases 2-nitro-5-thiobenzoate (TNB), which displays a maximum absorption at $412 \mathrm{~nm}$ [19]. The final labeled cysteine concentration was equal to protein concentration, indicating full accessibility, reactivity, and lack of disulfide bridge formation at cysteine 212, even after several weeks of storage without any reducing agent. The XlnS212C variant was then functionalized by incubation with 5 equiv. of the S7 Knölker's complex dissolved in DMSO overnight at $4{ }^{\circ} \mathrm{C}$, in coupling buffer (HEPES $10 \mathrm{mM}, 150 \mathrm{mM} \mathrm{NaCl}, \mathrm{pH}$ 7.75) (Fig. 1). This resulted in the formation of the XlnS212CK biohybrid, bearing Knölker's complex S7 covalently linked to cysteine 212, which was further characterized by MALDI-ToF mass spectrometry (Fig. 3). Peaks at 33,158 \pm 5 and 33,598 \pm 5 Da were, respectively, observed for the $\mathrm{X} \ln S 212 \mathrm{C}$ variant and for the xylanase A-derived biohybrid XInS212CK, in agreement with the covalent anchoring of one Knölker's complex S7 per protein after loss of three CO ligands (Fig. 3).

\subsection{Aqueous transfer hydrogenation of TFAC by metal complexes}

TFAC S8 was chosen as a benchmark substrate to delineate the catalytic activity of the newly synthesized complexes in aqueous transfer hydrogenation reactions using formate as a hydrogen source (Fig. 4). First, this substrate may be readily reduced into the corresponding $\alpha$-(trifluoromethyl)benzyl alcohol S9 thanks to the electron-attracting character of the $\mathrm{CF}_{3}$ substituent [26]. Second, TFAC is well known to be hydrogenated into asymmetric trifluoromethyl benzyl alcohol by naturally occurring hydrogenases like carbonyl reductase [27], which makes it a perfect candidate for studying the enantioselectivity of the catalysis.

The hydrogenation of TFAC was carried out in aqueous medium, under the following reaction conditions: a $25 \mathrm{mM}$ solution of the carbonyl substrate in HEPES buffer ( $\mathrm{pH} \mathrm{8)}$ was allowed to react at $65^{\circ} \mathrm{C}$ with $3 \mathrm{M}$ sodium formate in the presence of $90 \mu \mathrm{M}$ Me3NO and $30 \mu \mathrm{M}$ catalyst [28].

The same conditions were then chosen to explore the catalytic activity of the XInS212CK artificial hydrogenase, and the influence of XIn A on the kinetics and selectivity of the hydrogenation reaction catalyzed by Knölker's complex cofactor S7 was investigated.

\subsection{Hydrogenation of TFAC by the XInS212CK biohybrid}

The reaction was followed by gas chromatography using acetophenone as internal standard. Whereas the reaction was negligible in the absence of catalyst (data not shown), it was catalyzed by both the Knölker's iron complex S7 and the XIn A-Knölker's iron biohybrid complex XInS212CK. XInS212CK catalyzed the hydrogenation of TFAC into alcohol S9 with an initial rate of $8.8 \mu \mathrm{M} \cdot \mathrm{H}^{-1}$, whereas Knölker's complex S7 alone was poorly soluble in water thus producing alcohol S9 with an initial rate of only $2 \mu \mathrm{M} \cdot \mathrm{H}^{-1}$ (data not shown). Under these conditions, the reaction thus proceeded about 4.4-fold faster with the XInS212CK biohybrid than with the Knölker's complex S7 alone as catalyst. It is noteworthy that, in ethanol the Knökler's complex S7 was soluble and produced alcohol S9 with an initial rate of $2.6 \mu \mathrm{M} \cdot \mathrm{H}^{-1}$. Over time, the production of alcohol S9 slowed down to reach a plateau after about 60 H. After reaching the plateau, approximately 2.5-fold more alcohol S9 was produced in the presence of the biohybrid XlnS212CK than in the presence of the Knölker's complex S7 alone as catalyst (Fig. 5).

This confirmed that the XInS212CK biohybrid was a better catalyst for the hydrogenation of TFAC by sodium formate in water, which could potentially be explained by the fact that the protein scaffold may facilitate solubilization of the hydrophobic Knölker's complex and the TFAC substrate in water.

Finally, the enantiomeric excess was measured using a chiral GC column, as described in the Experimental section. Trifluoromethyl benzyl alcohol was formed as a racemic mixture, exhibiting poor control of the substrate orientation and/or stabilization inside the hydrophobic pocket of the XlnS212CK biohybrid.

\subsection{Virtual docking of TFAC to the XInS212CK biohybrid}

To rationalize these experimental results and to simulate a precoordination complex that could favor hydrogenation of the TFAC molecule, we performed virtual docking of this substrate to XInS212C and XInS212CK. Blind virtual docking was first performed on free XlnS212C to uncover pockets and/or 
preferred hotspots that favor TFAC binding to the enzyme. After testing over 1,000,000 blind docking combinations, we found that the most favorable TFAC ligand conformers are always preferentially positioned within a given subsite of the Xln A binding pocket $(\Delta G=-62 \mathrm{kcal} / \mathrm{mol}$, Fig. $6 \mathrm{~A})$. Even upon anchoring of the Knölker's complex to the enzyme scaffold, docking simulations illustrate that the most favorable TFAC-binding site remains unchanged, targeting the same active-site pocket within Xln A, even after conformational rearrangements of the active-site cavity ( $\Delta G$ values up to -81 $\mathrm{kcal} / \mathrm{mol}$, Fig. 6B-6D). Interestingly, none of our docking models show catalytically productive atomic coordination between the Knölker's complex and the TFAC substrate molecule, further supporting the lack of enantioselectivity conferred by the XlnS212CK biohybrid scaffold. Indeed, this observation suggests that the Knölker's complex is most likely flexible and can experience free rotational reorientation within the activesite pocket of Xln A, allowing it to access the subsite pocket populated by TFAC.

\subsection{Reaction mechanism}

Based on our results and previously reported work [29], a three-step mechanism can be proposed for the reduction of TFAC by sodium formate catalyzed by the XInS212CK biohybrid (Scheme 2). First, in agreement with the necessity to add Me3NO in the medium for the reaction to occur, it is reasonable to assume that oxidation by Me3NO of one CO ligand stabilized by the iron atom in the starting Knölker's complex $\mathbf{S 7}$ provides the activated 16-electron iron species $\mathbf{S 7 b}$. The subsequent hydrogen activation should lead to the hydride iron complex S7c [29].

The $\mathrm{C}=\mathrm{O}$ bond may then be reduced either through a one-step process (as shown in Scheme 1) or through a stepwise process. Finally, the reduced products are released and the Knölker's complex S7 regenerated.

\section{Conclusions}

In conclusion, we have demonstrated that a new artificial hydrogenase made by covalent grafting of the iron Knölker's complex $\mathbf{S 7}$ bearing a maleimido reactive function anchored to a xylanase S212C variant can efficiently catalyze the transfer hydrogenation of the benchmark substrate TFAC by sodium formate in water, yielding the corresponding secondary alcohol as a racemic. The reaction proceeded more than threefold faster with the XInS212CK biohybrid than with the Knölker's complex S7 alone. In addition, efficient conversion of TFAC to its corresponding alcohol was reached within $60 \mathrm{H}$ with XlnS212CK, whereas $\approx 2.5$-fold lower conversion was observed with Knölker complex S7 alone as catalyst. As previously reported for metal complexes such as metalloporphyrins [13, 14], this confirmed that incorporation of iron Knölker's complex S7 into the hydrophobic pocket of a protein such as Xln A is productive and favorable, most likely due to increased solubility provided by the protein scaffold for such hydrophobic substrate and Knölker moiety. In contrast, incorporation of the Knölker's complex in the chiral cavity of XInS212C did not induce the expected reaction enantioselectivity, suggesting poor control of substrate and/or Knölker's complex orientation with respect to the iron center within the active-site pocket of XIn A.

On the basis of these results, we aim to build new artificial metalloenzymes based on the same scaffold. To improve activity of the biohybrid catalyst, water-soluble metalloporphyrins incorporating different metal centers such as ruthenium will be synthesized. Improving enantioselectivity may be achieved either by chemical modifications such as using spacers of variable lengths between the xylanase protein and the Knölker's complex, or by performing additional mutagenesis within the active-site pocket of XIn A to better accommodate and improve complex stabilization.

\section{Acknowledgments}

The authors thank Nhung Nguyen-Thi and Roger Dubuc (INRS) for helpful technical assistance with protein expression and purification. This work was supported in part by a Discovery grant from the Natural Sciences and Engineering Research Council of Canada (NSERC) under award number RGPIN-2016-05557 (to N.D.), in addition to a grant from the National Institute of General Medical Sciences (NIGMS) of the National Institutes of Health (NIH) under award R01GM105978 (to N.D.). N.D. is the recipient of a Fonds de Recherche Québec - Santé (FRQS) Research Scholar Junior 2 Career Award (number 32743). This work was supported in part by an ANR grant Carb2zyme (ANR-17-CE11-0014-02) and the LabEx CHARM3AT (ANR-11-LABEX-0039)

\section{References}

[1] Ashby, E. C., and Boone, J. R. (1976) J. Am. Chem. Soc. 98, 5524-5531.

[2] Dickson, H. D., Smith, S. C., and Hinkle, K. W. (2004) Tetrahedron Lett. 45, 5597-5599.

[3] Du, D.-M., Fang, T., Xu, J., and Zhang, S.-W. (2006) Org. Lett. 8, 1327-1330.

[4] Johnson R. M., and Rickborn B. (1970) J. Org. Chem. 35, 1041-1045.

[5] Naota, T., Takaya, H., and Murahashi, S. I. (1998) Chem. Rev. 98, 2599-2660.

[6] Vivancos, Á., Beller, M., and Albrecht, M. (2018) ACS Catal. 8, 17-21.

[7] Schrock, R. R., and Osborn, J. A. (1976) J. Am. Chem. Soc. 98, 4450-4455.

[8] Mérel, D. S., Elie, M., Lohier, J.-F., Gaillard, S., and Renaud, J.-L. (2013) ChemCatChem 5, 2939-2945.

[9] Letondor, C., Humbert, N., and Ward, T. R. (2005) Proc. Natl. Acad. Sci. 102, 4683-4687.

[10] Schwizer, F., Okamoto, Y., Heinisch, T., Gu, Y., Pellizzoni, M. M., Lebrun, V., Reuter, R., Köhler, V., Lewis, J. C., and Ward, T. R. (2018) Chem. Rev. 118, 142-231.

[11] Mérel, D. S., Gaillard, S., Ward, T. R., and Renaud, J.-L. (2016) Catal. Lett. 146, 564-569.

[12] Ricoux, R., Dubuc, R., Dupont, C., Marechal, J.-D., Martin, A., Sellier, M., and Mahy, J.-P. (2008) Bioconjug. Chem. 19, 899-910.

[13] Ducros, V., Charnock, S. J., Derewenda, U., Derewenda, Z. S., Dauter, Z., Dupont, C., Shareck, F., Morosoli, R., Kluepfel, D., and Davies, J. G. (2000) J. Biol. Chem. 275, 23020-23026.

[14] Ricoux, R., Allard, M., Dubuc, R., Dupont, C., Maréchal, J.-D., and Mahy, J.-P. (2009) Org. Biomol. Chem. 7, 3208-3011. 
[15] Mahy, J.-P., Raffy, Q., Allard, M., and Ricoux, R. (2009) Biochimie 91, 1321-1323.

[16] Allard, M., Dupont, C., Muñoz Robles, V., Doucet, N., Lledós, A., Maréchal, J.-D., Urvoas, A., Mahy, J.-P., and Ricoux, R. (2012) ChemBioChem 13, 240-251.

[17] Uehara, T., Rokugawa, T., Kinoshita, M., Nemoto, S., Fransisco Lazaro, G., G., Hanaoka, H., and Arano, Y. (2014) Bioconjug. Chem. 25, 2038-2045.

[18] Richter, M., Chakrabarti, A., Ruttekolk, I. R., Wiesner, B., Beyermann, M., Brock, R., and Rademann, J. (2012) Chem. - Eur. J. 18, 16708-16715.

[19] Ellman, G. L. (1959) Arch. Biochem. Biophys. 82, 70-77.

[20] Ducros, V., Charnock, S. J., Derewenda, U., Derewenda Z.S., Dauter, Z., Dupont, C., Shareck, F., Morosoli, R., Kluepfel, D., and Davies, G.J. (2016) J .Biol. Chem. 275, 23020-23026.

[21] Lauck, F., Smith, C.A., Friedland, G.F., Humphris, E.L., and Kortemme, T. (2010) Nucleic Acids Res. 38, W569-W575.
[22] Kuriata, A., Gierut, A.M., Oleniecki, T., Ciemny, M.P., Kolinski, A., Kurcinski, M., and Kmiecik, S. (2018) Nucleic Acids Res. 46, W338-W343.

[23] Jamroz, M., Orozco, M., Kolinski, A., and Kmiecik, S. (2013) J Chem Theory Comput. 9,119-125.

[24] Suhre, K., and Sanejouand, Y.H. (2004) Nucleic Acids Res. 32, W610-W614.

[25] Thomsen, R., and Christensen, M.H. (2006) J Med Chem. 49, 3315-3321.

[26] Madern, N., Talbi, B., and Salmain, M. (2013) Appl. Organomet. Chem. 27, 6-12.

[27] Honda, K., Ono, T., Okano, K., Miyake, R., Dekishima, Y., and Kawabata, H., (2019) J. Biosci. Bioeng. 127, 145-149.

[28] Pagnoux-Ozherelyeva, A., Pannetier, N., Mbaye, M. D., Gaillard, S., and Renaud, J.-L. (2012) Angew. Chem. 124, 5060-5064.

[29] Lator, A., Gaillard, S., Poater, A., and Renaud, J.L. (2018) Chemistry 24 5770-5774. 